INTERNATIONAL JOURNAL OF RESEARCHES IN BIOSCIENCES, AGRICULTURE AND TECHNOLOGY (C) VISHWASHANTI MULTIPURPOSE SOCIETY (Global Peace Multipurpose Society) R. No. MH-659/13(N) www.ijrbat.in

\title{
INDIGENOUS TRADITIONAL KNOWLEDGE OF WILD EDIBLE NTFPS PLANT IN ARJUNI MOR TEHSIL OF GONDIA DISTRICT (MS), INDIA
}

\author{
Zode Ravindra ${ }^{1}$ and Chaturvedi Alka ${ }^{2}$ \\ 1Department of Botany, C. J. Patel College, Tirora, Dist.-Gondia \\ 2 Department of Botany, RTMN University, Nagpur \\ *Corresponding author email: ravizode31@gmail.com
}

\begin{abstract}
:
A study was undertaken to assess Indigenous traditional knowledge (ITK) of non-timber forest products (NTFPS) used as edible purpose in selected sites of Arjuni Mor tehsil of Gondia District, Maharashtra. In view of this, the present work was undertaken which documents as many as 60 plant species belonging to 55 genera and 41 families. Survey of wild edible plants has been carried out in 10 villages of Arjuni Mor tehsil of Gondia district, Maharashtra, India. The study showed that the plants used are either eaten raw, cooked by boiling in water, frying in oil or baked to be served as dishes such as stew, salad as hot drink.
\end{abstract}

Keywords: Wild edible plant, NTFPs, ITK and forest dwellers.

\section{INTRODUCTION:}

Non-timber forest products (NTFPs) are an integral part of development and survival of people living in and around forests and depending on them. One of the most important of NTFPs used as edible purpose (Shackleton et al., 2002a). Millions of people in many developing countries depend on wild resources including wild edible plants to meet their food needs especially in periods of food crisis (Balemie and Kebebew 2006). Many wild edible plants are nutritionally rich (Ogle and Grivetti 1985) and can supplement nutritional requirements, especially vitamins and micronutrients. Usage of wild edible plants as a nutrition is well documented among inhabitants of South America, where several hundred species have been recorded (Ladio \& Lozada, 2004). Kaur et al., (2011) studied on nutritional aspects of unconventional food consumed by gond and korku tribes inhabiting in Vidarbha. Realizing this fact, the use and conservation of wild edible plants in India has been emphasized by Arora and Pandey (1996).In Maharashtra, Susala Island of Pune district studied by Vartak and Suryanarayana (1995) have reported 130 wild edible plants, which provide food during food scarcity and famine. Zode et al. (2016) reported the forest products in the form of NTFPs in Nagbhir tehsil of Chandrapur district (MS) and stated the importance in the socio-economic security net on the forest dwellers. Similarly Zode et al. (2014) estimated that, total 45 plants used in various waywere identified as NTFPs in Tirora tehsil of Gondia district. Zode et al. (2015) studied in few villages of Gondia district and observed that, the people of the region are living in remote area which is covered by large forest and therefore they are more dependent on the NTFPs.

In view of this, the present authors felt the urgency of documenting the indigenous traditional knowledge from the local inhabitants the edible use of wild plants growing in their ambience.

\section{METHOD AND MATERIAL:}

Study area

The study was carried out in the 10 forest villages of Arjuni Mor tehsil of Gondia district (Figure 1 \& 2) where majority of the tribal gather wild edible plant NTFPs products from forest area.

The Primary data was collected through Participatory Rural Appraisal (PRA), group discussion, semi-structured interviews and household survey (Martin, 1995; Pretty et al., 1995). 
Questionnaire interviews were conducted in selected villages. Questions were asked in local language i.e. in Marathi and Hindi.

\section{RESULTS AND DISCUSSION}

An analysis of the wild edible species concerned with the documented ITK and dependence of the forest dwellers residing in study areas shows that angiosperms have major contribution in the "nontimber forest products" used in edible purpose. There are total 60 NTFPs species of 55 genera representing 41 families used in edible purpose. Of these, 45 species of 41 genera belong to 30 families of Dicotyledons. The Monocotyledons on the other hand contribute to NTFPs in the form of 11 species; belong to 10 genera of 7 families. Thus the dicots appear to be more used than monocots, the ratio at the level of families, genera and species being 4:2, 4:3 and 4:5, respectively (Table 1). Therefore, it concludes that greater dependency of the forest dwellers is on dicots than monocots (Fig. 3).This might lead to their depletion if the consumption is ruthless and irrational. As such there should be a periodic investigation of the flora of the place together with the assessment of their exploitation.

In addition to the angiosperms, the documented NTFPs include two family, genus and species of Pteridophyte, the name of the species being Marsilea quadrifolia and Lygodium flexuosum whereas two family, genus and species of fungi, the name of the species is Termitomyces species and Agaricus species.

Mostly used family from Dicot is Caesalpinaceae, contributing 4 species towards NTFPs followed by Anacardiaceae, Rhamnaceae, each of which contribute 3 species each. Among monocots the mostly used families are Araceae, Dioscoriaceae, Poaceae which contribute two species in use as NTFPs in the study area (Fig. 4).

An analysis of habit of the NTFPs generating species reveals that out of 60 NTFPs edible species $28(46$ $\%)$ are trees, 10 (17\%) shrubs, 16 (27\%) herbs and $4(7 \%)$ climbers and remaining $2(3 \%)$ are fungi
(Figure 1.5). Tree species are exploited more than others i.e. shrubs, herbs and climbers. A good number of species of herbs is used in contrast to shrubs and climbers. This observation is rather encouraging from conservational purview, since the indigenous traditional knowledge was found to spare trees from felling.

Furthermore, the heterogeneity as observed in the plant habit based vertical stratification of the forest community seems to have been maintained by the forest dwellers. Use of a few species of herbs and low number of shrubs means lesser interference with and exploitation of the forest floor. Maintenance of this kind of vertical stratification is of prime importance in rendering stability to the forest ecosystem.

So far the local status of total 60 NTFPs wild edible species is concerned, $13 \%$ were found to be rare and less common categories. The remaining species were observed to belong to "very common" (30 species i.e. $50 \%$ ), "common" (14 species i.e. $23 \%)$ (Fig. 6).

The taxa names of plant food resources and the parts used are enumerated in the table 3 . There were found that near about 13 plant parts used for edible purpose. Among them mostly utilized edible part were found ripe fruits, collected from 30 species (Fig. 7). Which are used to cater nutritional requirements of various forest dwellers of Arjuni Mor tehsil of Gondia district. According to local tradition, wild edible plants are consumed in many different such as ways 24 species are eaten raw, 24 species only cooked, 3 species are raw and cooked, 4 species are raw and pickled and 4 species are used as flavoring agents. Cooked and raw recipes constitute similar percentage i.e. $39 \%$ of the modes of consumption while other edibles follow with the relatively less percentage (Fig. 8).

The result shows that 72 plant parts were used out of the 60 edible plants recorded in the study area. This means that more than one part of the species was consumed by forest dwellers. The result 
indicates that 12 number of plant parts exceeds the number of available plants in the study area. The highest consumption of edible plant part comes from fruits followed by the unripe fruits. The study also revealed that tree species provide highest edible part for consumption.

The threat perception was analyzed by segregating the documented plants on the basis of their parts consumed and it was found that the species whose ripe and unripe fruits, seed, flowers, rhizome, tubers, stem bark, and fruiting body are consumed are exposed to high threat perception, whereas, the plant species whose leafy twig, young leaves, leaves, young stem and young inflorescences are consumed face low threat perception (Table 2).

In the present study medicinal wild vegetable species reported. Many wild vegetables are also being consumed for various medicinal purposes. The demarcation line between food and medicine may not always be clear. For example, Achyranthes aspera, leaf juice is used against cough, Alteranthera sessilis is against jaundice; Boerhavia diffusa, is against liver diseases (Jain, 2010).Such unconventional wild edible plants are sources of fats, proteins, rich source of micro-nutrients and trace elements (Kulkarni, 2006). According to Guptha et al., (2010) Boerhavia diffusa are used against urinary disorders. Tuber of Dioscorea bulbifera is used to avoid intestinal worms (Tayade and Patil, 2006). According to Etkin, (1994) wild foods are consumed not only for caloric value, but also for other nutrient and pharmacologic potential. Zode et al. (2017) studied in Salekasa tehsil of Gondia district and observed that, 85 NTFPs species used as wild edible plants by the forest dwellers.

\section{CONCLUSION:}

As most of the indigenous people live in forests and live mostly below poverty level, they have to depend on the forest flora for food purpose and easily accessible even during adverse conditions like drought and famine. As many as 60NTFPs species of food plants are recorded to use as edible plant but they have been under going shrinkage mainly due to habitat depletion. Forest ecosystem is likely to be damage if over - exploitation of these species. In view of these, the forests need to and be saved and strategically restored collaterally with economic welfare of the associated people and these species should be sustained as such. Such wild edible species are selected from the wildness for their large scale cultivation to address the issue of food security for the future generations.

\section{REFERANCE :}

Arora, R. K. \&Pandey A. (1996). Wild Edible Plants of India: Conservation and Use. National Bureau of plant Genetic Resources, New Delhi, India.

Balemie, K. \&Kebebew F. (2006).Ethnobotanical study of wild edible plants in Derashe and Kucha Districts, South Ethiopia.Journal of Ethnobiology and Ethnomedicine2:53.

Etkin, N.L. (1994). The call of wild, In: Eating on the Wild side, by N.L. Etkin (Ed.) university of Arizona Press, Trizona. pp.1-21.

Guptha, A., Nagariya A. K., Mishra, A. K., Bansal, P., Kumar, S., Guptha, V., \& A. K. Singh (2010). Ethnopotential of medicinal herbs in skin diseases: An overview journal of Pharmacy research. 3(3):435-441.

Jain, D. L., Baheti, A. M., Jain, S. R., \&Khandelwal, K. R. (2010). Use of medicinal plants among tribes in Satpuda region of Dhule and Jalgaon districts of Maharashtra an ethnobotanical survey.

Kaur, A., (2011). Studied on nutritional aspects of unconventional food consumed by gond and korku tribes inhabiting in Vidarbha. $\mathrm{Ph}$. D. thesis, Department of Botany, RTMNU, Nagpur.

Kulkarni D. K. (2006).Role of ethno-botany in Modern Agriculture.In Proceeding of National Conference on Bridging Gap between Ancient and Modern Technologies to Increase Agricultural Productivity, edited by Chudhary SL, Saxena RC and Nene YL (Pub. Central Arid Zone Research Institute) Jodhpur, Rajasthan, India 104-115.

Martin, G. (1995). Ethnobotany: a methods manual, Chapman y Hall. NowyJork.

Ogle, B. M. \&Grivetti, L. E. (1985). Legacy of the chameleon edible plants in the Kingdom 
ofSwaziland, South Africa.A cultural, ecological, nutritional study.Parts II-IV, species availability and dietary use, analysis by ecological zone.Ecology of Food and Nutrition $17: 1-30$.

Pretty, J. N., Guijt, I., Thompson, J., \&Scoones, I. (1995). Participatory learning and action: a trainer's guide.

Shackleton, C. M., Shackleton, S. E., Ntshudu, M., \&Ntzebeza, J. (2002). The role and value of savanna non-timber forest products to rural households in the Kat River Valley, South Africa. Journal of Tropical Forest Products, 8(1), 45-65.

Tayade. S. K and D. A. Patil(2006). Ethnomedicinal wisdom of Tribal of Nanduban District Maharashtra.Natural Product Radiance. 5(1):64-69.

Vartak, V.D. \&Suryanarayana, M. C. (I995). Enumeration of wild edible plants fromsusala Island, Mulshi reservoir, Pune district. J. Econ. Taxo. Bot., 19(3), 555-569.

Zode R.,\&Chaturvedi A. (2016). Role of NTFPs among Forest Villagers in a Nagbhir Tehsil, District Chandrapur (MS), India, Int. J. of Life Sciences, A6: 161-164.

Zode R., Shambharkar, R., \&Chaturvedi A., (2015) Current Status Of Non-Timber Forest Products And Its Use Pattern By Villagers Of Tirora Tehsil Of Gondia District Maharashtra, India. International Journal of Institutional Pharmacy and Life Sciences 5(5).

Zode R., Tagade W., \&Chaturvedi A., (2014) Biodiversity of NTFPs and its usages from Tirora Tehsil of Gondia District (MS), India, Int. J. of Life Sciences, Special Issue, A2:150-152.

Zode R. and Chaturvedi A., (2017)Current Status And Potential Of Wild Edible Plant Origin NTFPs In Salekasa Tehsil Of Gondia District (Ms), India, International Journal of Advance and Innovative Research, 4 (4), 51-58.

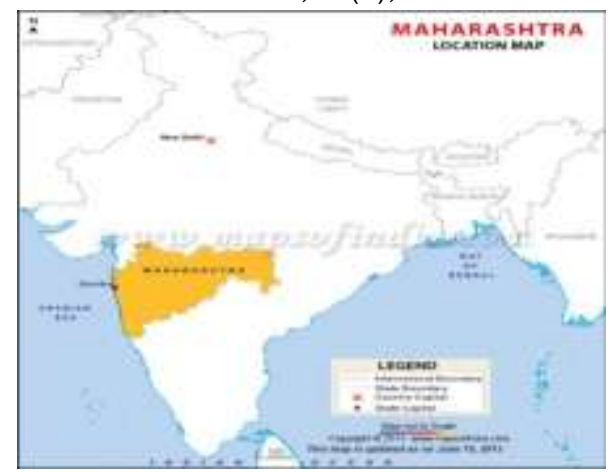

Fig. 1: Map showing Maharashtra state in India

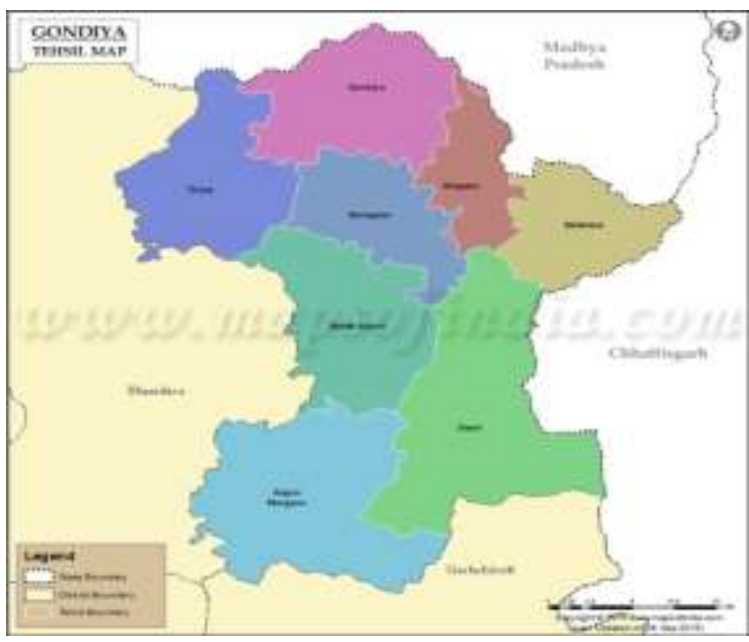

Fig. 2: Map showing Gondia district.
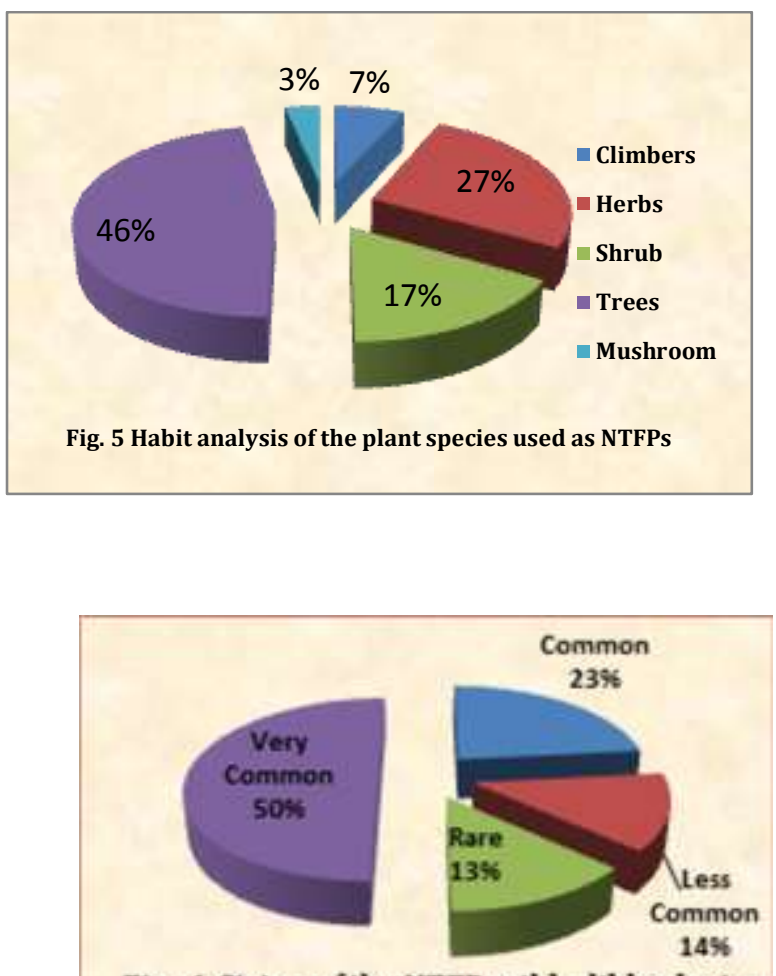

Fig. 6 Status of the NTFP-wild edible plant sp 
Table 1 Taxonomic analysis of Angiosperm (Dicots \& Monocots), Pteridophyte\& Fungi concerned with the indigenous traditional knowledge about wild edible NTFPs

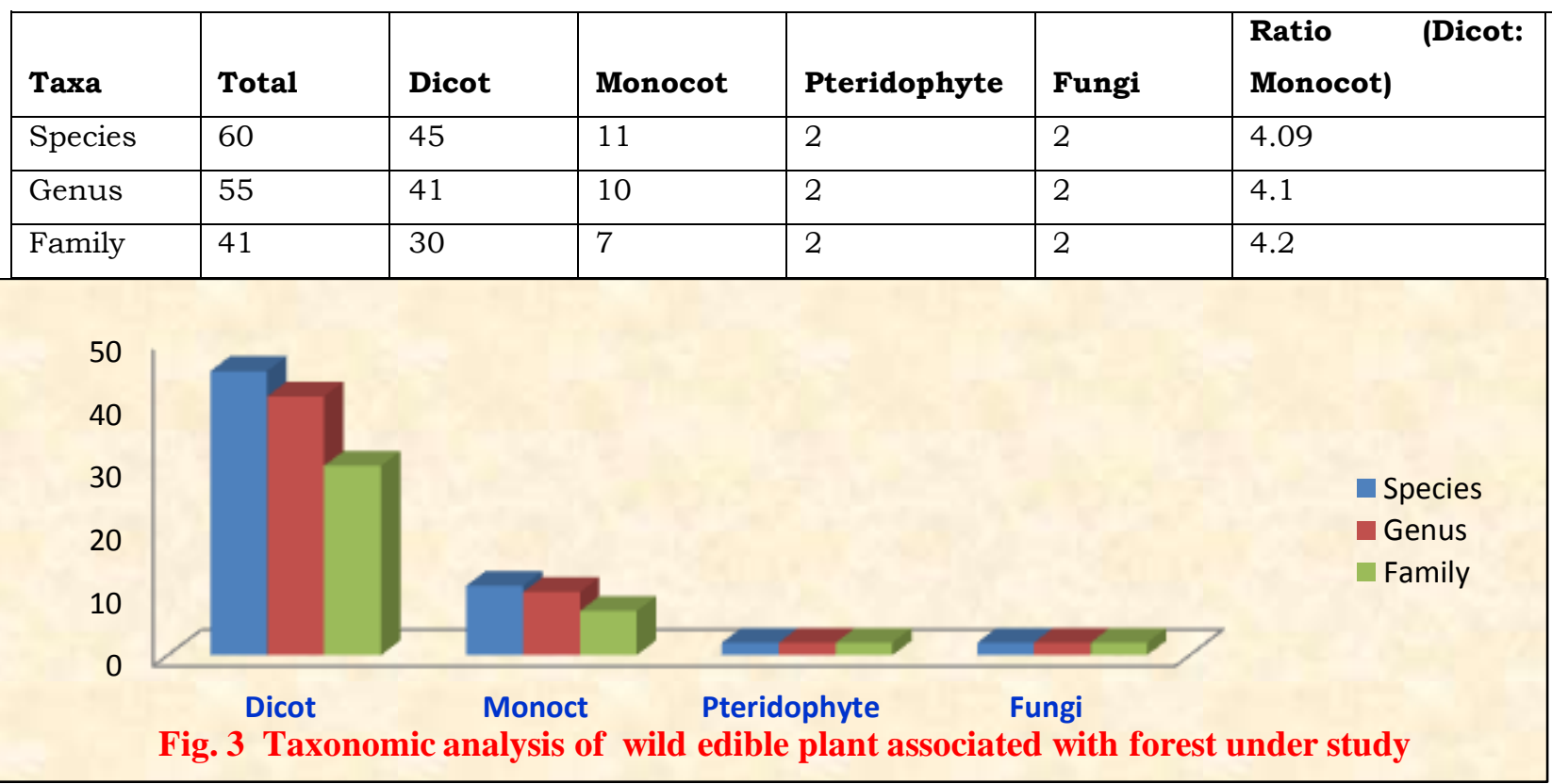
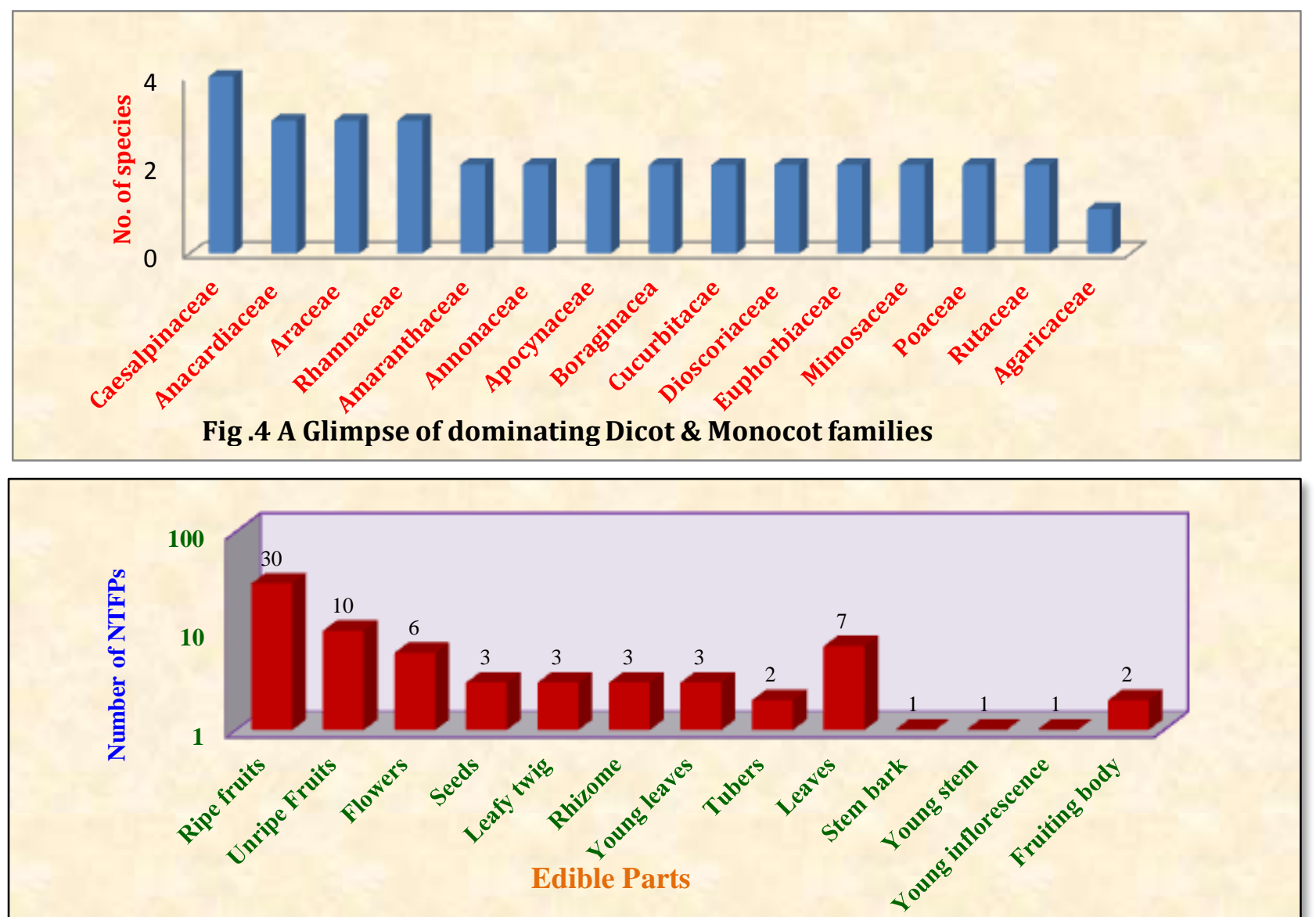

Fig. 7 Analysis of usable parts of edible wild plants of the study area 
species used as wild edible plants by the forest dwellers.

\begin{tabular}{|l|l|l|}
\hline \multicolumn{3}{|l|}{ Table 2 An analysis of the number of parts used } \\
per species and their threat perception \\
Plant parts & $\begin{array}{l}\text { Number of } \\
\text { species }\end{array}$ & $\begin{array}{l}\text { Threat } \\
\text { perception }\end{array}$ \\
\hline Ripe fruit & 30 & High \\
\hline Unripe fruit & 10 & High \\
\hline Flower & 6 & High \\
\hline Seeds & 3 & High \\
\hline Leafy twig & 3 & Low \\
\hline Rhizome & 3 & High \\
\hline Young leaves & 3 & Low \\
\hline Tubers & 2 & High \\
\hline Leaves & 7 & Low \\
\hline stem bark & 1 & High \\
\hline Young stem & 1 & Low \\
\hline Young inflorescence & 1 & Low \\
\hline Fruiting body & 2 & High \\
\hline
\end{tabular}

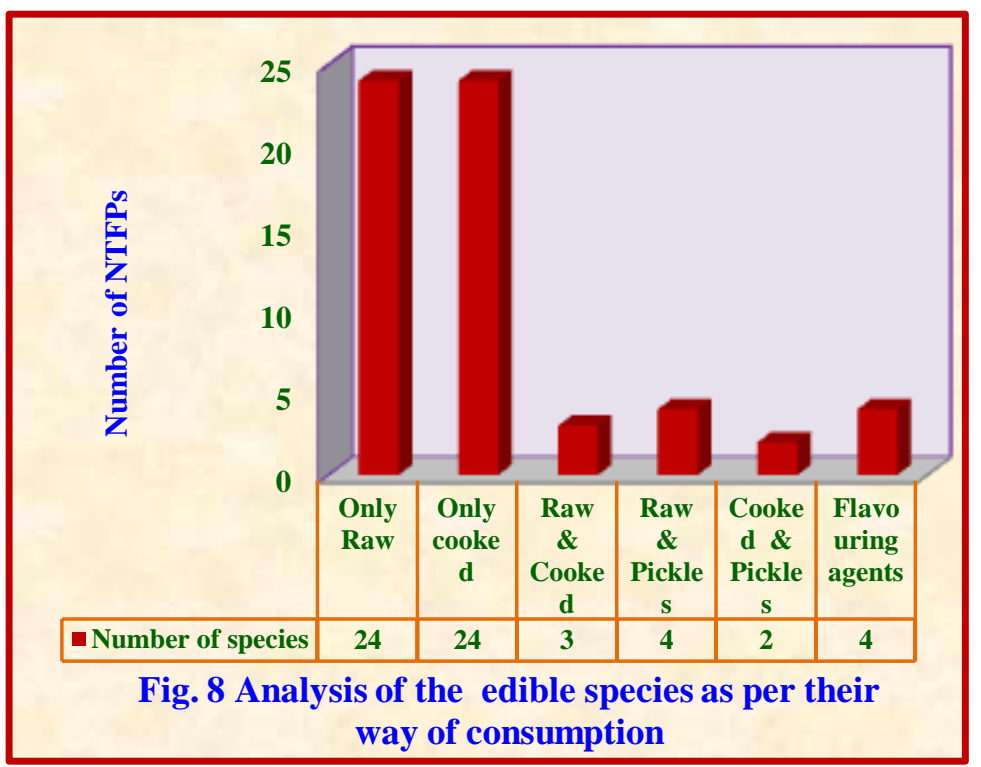

\begin{tabular}{|c|c|c|c|c|c|c|c|}
\hline $\begin{array}{l}\text { S. } \\
\mathbf{N} .\end{array}$ & Plant species & Family & Habit & $\begin{array}{l}\text { Sta } \\
\text { tus }\end{array}$ & $\begin{array}{l}\text { Local } \\
\text { name }\end{array}$ & $\begin{array}{c}\text { Edible } \\
\text { parts }\end{array}$ & Way of Consumption/ Dish prepared \\
\hline 1 & Acacia catechu & Mimosaceae & Trees & $\mathrm{C}$ & Khair & Stem bark & $\begin{array}{l}\text { Stem bark used as dye it is also Katha, one of the } \\
\text { ingredients of Pan (Flavouring agents). }\end{array}$ \\
\hline 2 & $\begin{array}{l}\text { Achyranthes } \\
\text { aspera }\end{array}$ & Amaranthaceae & Herbs & $\mathrm{VC}$ & Chilati & Seeds & Dry seeds are Eaten as raw. \\
\hline 3 & Aeglemarmelos & Rutaceae & Trees & $\mathrm{C}$ & Bel & $\begin{array}{l}\text { Ripe } \\
\text { Fruits } \\
\end{array}$ & Ripe fruits are eaten as raw. \\
\hline 4 & Agaricus sp. & Agaricaceae & Fungi & $\mathrm{C}$ & $\begin{array}{c}\text { Yerusaty } \\
\text { a }\end{array}$ & $\begin{array}{c}\text { Fruiting } \\
\text { body }\end{array}$ & Fruiting bodies are eaten as vegetables (Cooked). \\
\hline 5 & $\begin{array}{l}\text { Alangiumsalvi } \\
\text { folium }\end{array}$ & Alangiaceae & Trees & VC & Akawal & $\begin{array}{l}\text { Ripe } \\
\text { Fruits }\end{array}$ & Ripe fruits are eaten as vegetables (Cooked). \\
\hline 6 & Aloe vera & Liliaceae & Herbs & $\mathrm{VC}$ & Korphad & Leafy twig & Leaf twig are eaten as raw. \\
\hline 7 & $\begin{array}{l}\text { Alternanthera } \\
\text { sessile }\end{array}$ & Amaranthaceae & Herbs & vC & $\begin{array}{l}\text { Galighos } \\
\mathrm{h}\end{array}$ & Leafy twig & Leafy shoots are eaten as vegetables (Cooked). \\
\hline 8 & $\begin{array}{l}\text { Amorphophallusc } \\
\text { ampanulatus }\end{array}$ & Araceae & Herbs & $\mathrm{VC}$ & Suran & Rhizome & Rhizomes are eaten as a vegetable (Cooked). \\
\hline 9 & Annonareticulata & Annonaceae & Trees & LC & Ramfal & $\begin{array}{c}\text { Ripe } \\
\text { Fruits }\end{array}$ & Ripe fruits are eaten as raw. \\
\hline 10 & Annonasquamosa & Annonaceae & Trees & vC & Sitaphal & $\begin{array}{l}\text { Ripe } \\
\text { Fruits }\end{array}$ & Ripe fruits are eaten as raw. \\
\hline 11 & $\begin{array}{l}\text { Azadirachta } \\
\text { indica }\end{array}$ & Meliaceae & Trees & $\mathrm{C}$ & $\begin{array}{l}\text { Kadunim } \\
\mathrm{b}\end{array}$ & $\begin{array}{c}\text { Ripe } \\
\text { Fruits, } \\
\text { Young } \\
\text { leaves } \\
\end{array}$ & Frequently ripe fruits are eaten as raw. \\
\hline 12 & $\begin{array}{l}\text { Bauhinia } \\
\text { purpurea }\end{array}$ & Caesalpiniaceae & Trees & $\mathrm{C}$ & $\begin{array}{l}\text { Kanchan } \\
\text { vrush }\end{array}$ & $\begin{array}{l}\text { Flowers, } \\
\text { Ripe } \\
\text { Fruits }\end{array}$ & $\begin{array}{l}\text { Flowers are eaten as vegetables in the form of } \\
\text { "Bhaje" (Cooked) \& Fruits are eaten as vegetables } \\
\text { (CooKed). }\end{array}$ \\
\hline 13 & $\begin{array}{l}\text { Boerhaviarepens } \\
\text { var. diffusa }\end{array}$ & Nyctaginaceae & Herbs & LC & $\begin{array}{c}\text { Khapark } \\
\text { uti }\end{array}$ & Leaves & $\begin{array}{l}\text { Leaves are eaten as Vegetables - } \\
\text { KhaparkhutichiBhaji(Cooked). }\end{array}$ \\
\hline 14 & $\begin{array}{l}\text { Buchananiacochi } \\
\text { nchinensis }\end{array}$ & Anacardiaceae & Trees & $\mathrm{VC}$ & Charoli & $\begin{array}{l}\text { Ripe } \\
\text { Fruits, } \\
\text { Seeds }\end{array}$ & Ripe fruits are eaten as raw. \\
\hline 15 & Careyaarborea & Lecythidaceae & Trees & $\mathrm{LC}$ & Kumbhi & Ripe fruit & Ripe fruits are eaten as raw. \\
\hline
\end{tabular}




\begin{tabular}{|c|c|c|c|c|c|c|c|}
\hline 16 & Carissa carandus & Apocynaceae & Shrubs & $\mathrm{C}$ & $\begin{array}{l}\text { Karvand } \\
\quad \mathrm{a}\end{array}$ & $\begin{array}{l}\text { Unripe } \\
\text { Fruits }\end{array}$ & $\begin{array}{l}\text { Unripe fruits are eaten as raw and also used in the } \\
\text { preparation of pickles. }\end{array}$ \\
\hline 17 & Cassia fistula & Caesalpinaceae & Trees & $\mathrm{C}$ & Bahawa & Flowers & Flowers are eaten as vegetables (Cooked). \\
\hline 18 & Cassia tora & Caesalpiniaceae & Herbs & $\mathrm{VC}$ & Tarota & $\begin{array}{l}\text { Young } \\
\text { leaves }\end{array}$ & Young leaves are eaten as vegetables (Cooked). \\
\hline 19 & Cocciniagrandis & Cucurbitacae & Climbers & $\mathrm{VC}$ & $\begin{array}{l}\text { Jungalik } \\
\text { undru }\end{array}$ & $\begin{array}{l}\text { Unripe } \\
\text { fruits }\end{array}$ & Unripe Fruits are eaten as vegetables (Cooked). \\
\hline 20 & $\begin{array}{l}\text { Colocasia } \\
\text { esculenta }\end{array}$ & Araceae & Herbs & $\mathrm{LC}$ & Dhopa & Leaves & $\begin{array}{l}\text { Leaves are eaten as Vegetable (Cooked) i. e. } \\
\text { Called as Pan wadi }\end{array}$ \\
\hline 21 & $\begin{array}{l}\text { Commelinabengh } \\
\text { alensis }\end{array}$ & Commelinaceae & Herbs & $\mathrm{VC}$ & Kena & Leafy twig & Young plant eaten as Vegetable (Cooked). \\
\hline 22 & Cordiadichotoma & Boraginacea & Trees & $\mathrm{C}$ & $\begin{array}{l}\text { Shelwat, } \\
\text { Bhokar }\end{array}$ & $\begin{array}{l}\text { Ripe \& } \\
\text { Unripe } \\
\text { Fruits }\end{array}$ & $\begin{array}{l}\text { Unripe Fruits are eaten as vegetables (Cooked) } \\
\text { and also used in the preparation of pickles. Ripe } \\
\text { fruits are eaten as raw. }\end{array}$ \\
\hline 23 & Cordiagharaf & Boraginacea & Trees & $\mathrm{C}$ & $\begin{array}{l}\text { Shelwat, } \\
\text { Gondani }\end{array}$ & $\begin{array}{l}\text { Ripe \& } \\
\text { Unripe } \\
\text { Fruits }\end{array}$ & $\begin{array}{l}\text { Unripe Fruits are eaten as vegetables (Cooked). } \\
\text { Ripe fruits are eaten as raw. }\end{array}$ \\
\hline 24 & Curcuma longa & Zingiberaceae & Herbs & $\mathrm{LC}$ & Halad & Rhizome & $\begin{array}{l}\text { Rhizome is taken as edible wild when it fresh and } \\
\text { Powder of rhizome used as spice (Cooked) } \\
\text { \&flavouring agent. }\end{array}$ \\
\hline 25 & $\begin{array}{l}\text { Cymbopogon } \\
\text { nardus }\end{array}$ & Poaceae & Herbs & $\mathrm{C}$ & $\begin{array}{l}\text { Gawatich } \\
\text { aha }\end{array}$ & Leaves & $\begin{array}{l}\text { Whole plants used as flavouring agent during } \\
\text { making Tea (Cooked). }\end{array}$ \\
\hline 26 & $\begin{array}{l}\text { Dendrocalamusst } \\
\text { rictus }\end{array}$ & Poaceae & Shrubs & $\mathrm{VC}$ & Bamboo & $\begin{array}{l}\text { Young } \\
\text { stem }\end{array}$ & $\begin{array}{l}\text { Base of stem (Young stem bud) are eaten as a } \\
\text { vegetables (Vaste), Pakoda (Cooked). }\end{array}$ \\
\hline 27 & Dioscoreaalata & Dioscoriaceae & Climbers & $\mathrm{R}$ & Matalu & Tubers & $\begin{array}{l}\text { Tubers are eaten as a vegetables } \\
\text { (Cooked).Tuberous root are used to prepare the } \\
\text { stir-fried chips and are eaten during religious } \\
\text { fasting. }\end{array}$ \\
\hline 28 & $\begin{array}{l}\text { Dioscorea } \\
\text { bulbifera }\end{array}$ & Dioscoriaceae & Climbers & $\mathrm{R}$ & Matalu & Tubers & Tubers are eaten as a vegetable (Cooked). \\
\hline 29 & $\begin{array}{l}\text { Diospyrosmelano } \\
\text { xylon }\end{array}$ & Ebenaceae & Trees & $\mathrm{VC}$ & $\begin{array}{l}\text { Tendupat } \\
\text { ta }\end{array}$ & Ripe fruits & Ripe fruits are eaten as raw. \\
\hline 30 & Embilcaofficinalis & Euphorbiaceae & Trees & $\mathrm{VC}$ & Awala & $\begin{array}{l}\text { Ripe \& } \\
\text { Unripe } \\
\text { Fruits }\end{array}$ & $\begin{array}{l}\text { Unripe fruits are eaten as raw and also used in the } \\
\text { preparation of pickles. }\end{array}$ \\
\hline 31 & Ficus racemosa & Moraceae & Trees & $\mathrm{VC}$ & Umber & Ripe fruits & Ripe fruits are eaten as raw. \\
\hline 32 & Grewiaasiatica & Tiliaceae & Shrubs & $\mathrm{R}$ & Phaalsa & Ripe fruits & Ripe fruits are eaten as raw. \\
\hline 33 & $\begin{array}{l}\text { Holarrhena } \\
\text { pubescens }\end{array}$ & Apocynaceae & Trees & $\mathrm{VC}$ & $\begin{array}{l}\text { Pandhara } \\
\text { kuda }\end{array}$ & $\begin{array}{l}\text { Flowers, } \\
\text { Unripe } \\
\text { fruits }\end{array}$ & Flowers are eaten as vegetables (Cooked). \\
\hline 34 & Lantana camera & Verbenaceae & Shrubs & $\mathrm{VC}$ & Ghaneri & Ripe fruits & Ripe fruits are eaten as raw. \\
\hline 35 & $\begin{array}{l}\text { Limonia } \\
\text { acidissima }\end{array}$ & Rutaceae & Trees & $\mathrm{R}$ & Kawath & Ripe fruits & $\begin{array}{l}\text { Ripe fruits are eaten as raw and used to make the } \\
\text { chatney (Pickles). }\end{array}$ \\
\hline 36 & $\begin{array}{l}\text { Lygodium } \\
\text { flexuosum }\end{array}$ & Polypodiaceae & Herbs & $\mathrm{C}$ & $\begin{array}{l}\text { Jatashan } \\
\text { kar }\end{array}$ & Leaves & $\begin{array}{l}\text { Young leaves are fried with oil and used as } \\
\text { vegetable (Cooked). }\end{array}$ \\
\hline 37 & $\begin{array}{l}\text { Madhuca } \\
\text { longifolia }\end{array}$ & Sapotaceae & Trees & $\mathrm{VC}$ & Mahua & $\begin{array}{l}\text { Ripe } \\
\text { Fruits, } \\
\text { Flower }\end{array}$ & Ripe fruits are eaten as raw. \\
\hline 38 & $\begin{array}{l}\text { Mallotus } \\
\text { philippensis }\end{array}$ & Euphorbiaceae & Trees & $\mathrm{C}$ & Shendi & Ripe fruits & Ripe Fruits are eaten as raw. \\
\hline 39 & Mangifera indica & Annacardiaceae & Trees & $\mathrm{VC}$ & Aam & $\begin{array}{l}\text { Ripe \& } \\
\text { Unripe } \\
\text { Fruits }\end{array}$ & $\begin{array}{l}\text { Unripe fruits are eaten as raw and also used in the } \\
\text { preparation of pickles. }\end{array}$ \\
\hline
\end{tabular}




\begin{tabular}{|c|c|c|c|c|c|c|c|}
\hline 40 & $\begin{array}{l}\text { Marsilea } \\
\text { quadrifolia }\end{array}$ & Marsileaceae & Herbs & $\mathrm{R}$ & - & Leaves & Leaves are eaten as Vegetables (Cooked). \\
\hline 41 & $\begin{array}{l}\text { Maytenuss } \\
\text { enegalensis }\end{array}$ & Celastraceae & Shrubs & $\mathrm{VC}$ & Bharati & $\begin{array}{l}\text { Infloresce } \\
\text { nces }\end{array}$ & $\begin{array}{l}\text { Young inflorescences are eaten as vegetables } \\
\text { (Cooked). }\end{array}$ \\
\hline 42 & $\begin{array}{l}\text { Momordica } \\
\text { dioica }\end{array}$ & Cucurbitacae & Climbers & $\mathrm{LC}$ & Katwel & $\begin{array}{l}\text { Unripe } \\
\text { fruits }\end{array}$ & Unripe Fruits are eaten as vegetables (Cooked). \\
\hline 43 & Moringa oleifera & Moringaceae & Trees & $\mathrm{VC}$ & Shevaga & $\begin{array}{l}\text { Unripe } \\
\text { fruits }\end{array}$ & Unripe Fruits are eaten as vegetables (Cooked). \\
\hline 44 & Musa paradisiaca & Musaceae & Shrub & $\mathrm{C}$ & Kela & Ripe fruits & Ripe fruits are eaten as raw. \\
\hline 45 & $\begin{array}{l}\text { Nymphaea } \\
\text { pubescens }\end{array}$ & Nymphaeceae & Herbs & $\mathrm{VC}$ & Kamal & $\begin{array}{l}\text { Fruits, } \\
\text { Flower, } \\
\text { Rhizome }\end{array}$ & $\begin{array}{l}\text { Ripe fruits and Flowers are eaten as raw and } \\
\text { Rhizome is eaten as vegetables (Cooked). }\end{array}$ \\
\hline 46 & $\begin{array}{l}\text { Ocimum } \\
\text { tenuiflorum }\end{array}$ & Lamiaceae & Herbs & $\mathrm{VC}$ & Tulas & Leaves & $\begin{array}{l}\text { Younge leaves are as a raw. Fresh leaves are used } \\
\text { to make a Tea for of good flavour (Cooked) }\end{array}$ \\
\hline 47 & Olax psittacorum & Olacacea & Shrubs & $\mathrm{VC}$ & Hartfari & $\begin{array}{l}\text { Young } \\
\text { leaves }\end{array}$ & Young leaves are eaten as vegetables (Cooked). \\
\hline 48 & $\begin{array}{l}\text { Oroxylum } \\
\text { indicum }\end{array}$ & Bignoniaceae & Trees & $\mathrm{R}$ & Tetu & $\begin{array}{l}\text { Flower \& } \\
\text { Unripe } \\
\text { fruit }\end{array}$ & $\begin{array}{l}\text { Flowers are eaten as vegetables (Cooked) and } \\
\text { Unripe fruits are used in the preparation of } \\
\text { pickles. }\end{array}$ \\
\hline 49 & Phoenix sylvestris & Palmae & Trees & $\mathrm{VC}$ & Sindi & Ripe fruits & Ripe fruits are eaten as raw (Shindoli). \\
\hline 50 & $\begin{array}{l}\text { Pithecellobiumdul } \\
\text { ce }\end{array}$ & Mimosaceae & Trees & $\mathrm{VC}$ & Chichbili & Ripe fruits & Ripe fruits are eaten as raw. \\
\hline 51 & $\begin{array}{l}\text { Semecarpus } \\
\text { anacardium }\end{array}$ & Anacardiaceae & Trees & $\mathrm{VC}$ & $\begin{array}{l}\text { Bhelau, } \\
\text { Bibba }\end{array}$ & Ripe fruits & $\begin{array}{l}\text { Young cups (Receptacle) are used eaten as } \\
\text { vegetables (Cooked). Ripe yellow fleshy cups } \\
\text { (Receptacle) commonly used eaten as raw. }\end{array}$ \\
\hline 52 & Syzygium cumini & Myrtaceae & Trees & $\mathrm{VC}$ & Jambhul & Ripe fruits & Ripe fruits are eaten as raw. \\
\hline 53 & $\begin{array}{l}\text { Tamarindus } \\
\text { indica }\end{array}$ & Caesalpiniaceae & Trees & $\mathrm{LC}$ & Chinch & $\begin{array}{l}\text { Ripe \& } \\
\text { Unripe } \\
\text { Fruits }\end{array}$ & Ripe and unripe fruits are eaten as raw. \\
\hline 54 & $\begin{array}{l}\text { Terminalia } \\
\text { bellerica }\end{array}$ & Combretaceae & Trees & $\mathrm{C}$ & Behada & Seeds & Ripe and unripe fruits are eaten as raw. \\
\hline 55 & Termitomyces sp. & Trichlomataceae & & $\mathrm{R}$ & $\begin{array}{c}\text { Bhombo } \\
\text { di }\end{array}$ & $\begin{array}{c}\text { Fruting } \\
\text { body }\end{array}$ & Fruiting bodies are eaten as vegetables (Cooked). \\
\hline 56 & $\begin{array}{l}\text { Theriophonum } \\
\text { indicum }\end{array}$ & Araceae & Herbs & $\mathrm{VC}$ & Undirkan & Leaves & Leaves are eaten as Vegetables (Cooked). \\
\hline 57 & Trapanatans & Trapaceae & Herbs & $\mathrm{LC}$ & Shingada & Ripe fruits & $\begin{array}{l}\text { Fruits are eaten as raw (Cooked), Young fruits are } \\
\text { crushed with water and make Khir (Juice). }\end{array}$ \\
\hline 58 & $\begin{array}{l}\text { Ziziphus } \\
\text { caracutta }\end{array}$ & Rhamnaceae & Shrubs & $\mathrm{R}$ & Katbor & Ripe fruits & Ripe fruits are eaten as raw. \\
\hline 59 & $\begin{array}{l}\text { Ziziphus } \\
\text { mauritiana }\end{array}$ & Rhamnaceae & Shrubs & $\mathrm{VC}$ & Ber & Ripe fruits & $\begin{array}{l}\text { Ripe fruits are eaten as raw. Dry fruits boiled with } \\
\text { water and sugar and eaten as Borkutkatli } \\
\text { (Cooked). }\end{array}$ \\
\hline 60 & Ziziphus oenoplea & Rhamnaceae & Shrubs & $\mathrm{VC}$ & Aeroni & Ripe fruits & Ripe fruits are eaten as raw. \\
\hline
\end{tabular}

